\section{CREATIVE THINKING LEVELS DF PRESERVICE SCIENCE TEACHERS IN TERMS DF DIFFERENT VARIABLES}

\section{Selda Bakır, Esra Öztekin}

\section{Introduction}

The goal of traditional education is to give an individual knowledge and skills and prepare them to join society, but it is clear that traditional methods are not able to educate individuals who can make a valuable contribution to science and technology, which is changing rapidly. The goals of contemporary education systems are to teach individuals where and how to find the knowledge and skills they need, and to train up creative individuals who can adapt to changing societal conditions and generate new and unique solutions for all kinds of problems (Razon, 1990; Demirel, 1993).

Creative people know their own ways of thinking and take responsibility for directing and regulating these methods; they explain uncommon ideas in uncommonly clear ways, develop important inventions, arrive at different points of views, judgments and insights, and explain the world with original ways and writing (Yontar, 1993; Üstündağ, 2009). Creative people can take risks, establish a connection between existing facts and make a discovery, and in this way they can develop new technologies and procedures (Rawlinson, 1998). Açıkgöz (2003) lists the characteristics of creative people as follows: not being afraid of making a mistake, not being afraid of attempting something that comes to mind, and desiring to produce original results, even though they know that they won't be appreciated. It is enough for them to know it is creative. Creative people are universal; they like formulating problems, creating rules, and looking at events and objects with a new and different point of view (Stenberg and Lubart, 1993).

\section{What Is Creativity?}

The first scientific studies on the concept of creativity were done in 1950s by the American Psychological Association under the chairmanship of Guilford (Edgar, Faulkner, Franklin, Knobloch \& Morgan, 2008). What is creativ-
J O R N A L

$\mathrm{O} F \bullet \mathrm{B} A \mathrm{~L} T \mathrm{I} C$

$S$ C I E N C E

EDUCATION

ISSN 1648-3898

Abstract. The aim of this study was to determine the creative thinking levels of preservice science teachers in terms of different variables such as gender, year of study, the type of school they graduated from and their parents' educational background. The study was carried out on 241 preservice science teachers. The data collection tools applied were the Torrance Tests of Creative Thinking (Figural Form A), which was used to measure their creative thinking levels, and the Individual Information Form, which was developed by the researchers. The study revealed that the creative thinking levels of preservice science teachers do not differ significantly with respect to gender, year of study, the type of school they graduated from, or their parents' educational background.

Key words: creative thinking, preservice science teachers.
Selda Bakır, Esra Öztekin Mehmet Akif Ersoy University, Burdur, Turkey 
ity? Creativity is one of the most difficult concepts to define (Üstündağ, 2009; Plucker \& Nowak, 2001). There has been different definition about creativity in literature. Torrance (1974) defined creativity as;

(...) a process of becoming sensitive to problems, deficiencies, gaps in knowledge, missing elements, disharmonies, and so on; identifying the difficulty; searching for solutions, making guesses, or formulating hypotheses about the deficiencies: testing and retesting these hypotheses and possibly modifying and retesting them; and finally communicating the results (p. 8).

According to Yıldırım (1998), who defines creativity in terms of intellectual functions, and Çellek (2004), creativity is producing new concepts or ideas out of the relationships between existing concepts. In other words, creative thinking is related to innovating or making something different. Ömeroğlu and Turla (2001) and Argun (2004) expands on the above by stating that Creative thinking is an individual's distinctive way of thinking which is characterized by seeking innovation, being able to find new solutions for old problems, being an innovator, using previously unknown methods, and combining things in a different way. Üstündağ (2009: p.5) defines creativity as "something that makes you say"aha!"; it is taking risks to produce a new discourse, behavior, attitude, skill, product, philosophy of life, etc. in any cognitive, affective or kinetic activity".

From the above, it becomes evident that creative thinking is not a single skill, but involves many dimensions such as being sensitive to problems, fluency (being able to produce many ideas and associations), flexibility (producing different ideas about the same stimulus and using approaches that are different from each other), originality (producing new, uncommon and rare ideas) and elaboration (applying careful and detailed processing to expand on a simple stimulus that is available) (Guilford, 1950; Torrance \& Goff, 1979).

Guilford (1950) indicates that the creative thinking is a mental process involves constitutes convergent and divergent thinking. Convergent thinking can be defined as a single, consistent answer for a problem (Üstündağ, 2009). Divergent thinking on the other hand refers to abandoning old, stereotyped ideas, using objects in new ways, establishing new connections and expanding the limits of our knowledge and thinking processes (Üstündağ, 2009). Lately, there is a growing admittance that creative process require the integration of convergent and divergent thinking (Barok, 2009).

\section{Can It Be Improved?}

While some people deal with creativity assumed that creativity can be tought, the others believed that creativity was a natural, inborn speciality in the latter half of the twenty century. Although perceptions about creativity has changed over the past thirty years, there still is a controversy about creativity. But people on both sides of this controversy generally acknowledge that the people are born with a genetically specified of range of creative ability that can be enhanced and fostered (Plucker \& Nowak, 2001).

Özden (1999) claims that the answer to the question of whether creativity is an innate skill or whether it can be get later is an emphatic 'yes' in both cases. Özden (1999) goes on to say that some people have a combination of creativity and superior intelligence from birth, and that no education program can turn a normal person into someone like Avicenna, al-Farabi, Edison or Einstein, but that everyone can still develop their creative potential within their genetic limitations. According to Özden (1999) and Karkockiene (2005), when programs offer people the opportunity to use and develop the creative potential they have been born with, superb results can be achieved.

Creativity is a characteristic that every person has in different areas and to different degrees. In other words, everyone can be more or less creative (Kırışoğlu, 2002; Artut, 2004). The differences in creative activity depend on a person's heritage, cultural context, and education (Kırışoğlu, 2002). To be creative, first of all a person should believe in herself/himself, should think independently, should sometimes not consider the usual patterns and rules to be important, and should have freedom and the necessary environment to use his/her skills. When these factors are examined, it is seen that some aspects of creativity are based on psychological aspects such as character and personality structure, some aspects are based on social and environmental issues and some aspects are based upon educational issues (Adıgüzel, 2002). The skill of creative thinking is developed through a person's interaction with their environment, family, school and society. In other words, a positive and accepting environment can improve creativity (Süzen, 1987).

Creativity is fostered by environments where children are allowed to work independently, take responsibility for their own learning and do not have to fear taking risks and making mistakes. Children should be allowed to 
freely speak their thoughts, they should not be hindered or limited, they should be prompted to pursue creative thoughts and behavior, and they should be encouraged to use all of their skills (Razon, 1990; Özden,1999; Açıkgöz, 2003; Argun, 2004). According to Rawlinson (1995) and Yıldırım (1998), teaching style is the most important connection between creativity and education. Razon (1990) and Öztürk (2004) state that children raised in an educational environment that fosters creativity are happier, more productive and much more prolific than children raised in a restrictive environment. Family is an important factor in education and creativity. Creative families take their child's viewpoint into consideration when making decisions. When families are supportive of their children, this helps the child to develop creative thinking skills (Sungur, 2003; Süzen, 1987; Yavuzer, 1989; Argun, 2004; Singer \& Singer, 1998).

\section{Researches Related to Creativity}

Many studies have been done on creative thinking. A review of these studies shows that they can be grouped into two categories: first, experimental studies done to identify the effect that teaching methods have on creative thinking and the effect that creative thinking techniques have on creativity and other academic criteria (academic success, attitude, etc.), and second, descriptive studies that investigate creative thinking from the perspective of different variables.

Experimental studies in the first group that have investigated how creative thinking is affected by methods such as active learning techniques, project-based learning and problem-based learning have shown that studentcentered methods have a positive effect on creative thinking (Süzen, 2007; Korkmaz, 2002; Yaman \& Yalçın, 2005; Stephens, 2010; Karkockiene, 2005). Other experimental studies have shown that creative thinking techniques such as synectics, creative problem solving, divergent thinking techniques and brainstorming have an effect on creativity (Candar, 2009; Ceran, 2010; Öztürk, 2007; Ercan, 2010; Aksoy, 2005; Kaptan\& Kuşakçı, 2002; Pulgar Neira \& Sanchez Soto, 2013 and Lee, 2004) as well as academic success (Ceran, 2010; Oğuz, 2002; Pulgar Neira \& Sanchez Soto; 2013, and Aksoy, 2005) and attitude (Oğuz, 2002; Aksoy, 2005).

Descriptive studies in the second group can be divided into two subgroups: studies that evaluate the attitudes of preservice teachers towards creative thinking, and studies that evaluate creative thinking with regard to factors such as age, gender, parents' educational level, teacher effectiveness etc. Davidovitch and Milgram (2006) made a study with 58 lecturers for the purpose of investigating the relation between creative thinking and teacher effectiveness defined as real-life problem solving in teaching in higher education. A strong relation was found between creative thinking and teacher effectiveness defined as real life problem solving in the study. A study done by Newton and Newton (2009) determined that the level of creativity in preservice teachers was deficient in some ways and that these teachers were unable to understand all the different dimensions of issues that required creativity. The study concluded that there is a strong and positive relationship between creative thinking and effective teaching. Kim, Lee and Seo (2005) found that in Korean science teachers, creativity was related to mental faculties such as originality, problem solving and thinking skills. Ersükmen (2010) performed a study to identify the attitudes of science and technology teachers towards creativity and practices related to creativity, finding that the teachers were aware of concepts such as creativity and the characteristics of creative individuals. The teachers also knew about techniques needed for creative education and were applying them as much as possible. Halàkovà (2007) measured the various dimensions of creativity (fluency, flexibility, originality and attention to detail) in preservice science teachers using Torrance Tests of Creative Thinking and found a significant relationship between fluency and flexibility. Studies that investigated other factors of creativity (age, gender, family's educational status, etc.) arrived at different conclusions. Some of these studies found that age has a general effect on creativity (Hu \& Adey; 2002; Çetingöz, 2002; Öncü, 1989), while Atay (2009) found that age has an effect on the dimensions of originality and elaboration in creativity but does not affect fluency and flexibility. Studies by Güngör (2007), Konak (2008), Ercan, (2003) and Potur and Baykul (2009) found that there was no significant difference between genders when it comes to creative thinking. However, Atay (2009) found that gender affects the dimensions of fluency, flexibility and elaboration, Özben and Argun (2000) found that it affects fluency and flexibility, and Öztunç (1999) and Tegano and Moran (1989) found a significant difference between genders with regard to creative thinking. Güngör (2007), Konak (2008) and Çetingöz (2002) studied creative thinking from the aspect of the family's educational status and found no significant differences, but studies by Ercan (2003), Şen (1999) and Öztunç (1999) did find a significant effect. A study by Atay (2009) found that students whose parents had primary school education had higher scores for the dimensions of fluency and elaboration than other children but did not find any significant difference in 
any of the other aspects. In a study that investigated creative thinking based on class level, Konak (2008) and Şen (1999) found a significant difference. In addition, Güngör (2007) found a significant difference between the subdimensions of creativity in class levels. In studies evaluating creative thinking based on the type of high school the student graduated from, Potur and Baykul (2009) and Özben and Argun (2000) found a significant difference, while a study by Öztunç (1999) did not find any significant difference.

In summary, it can be said that experimental studies on creativity have generally shown that creative thinking techniques and methods which involve active participation on the part of the student have a positive effect on creative thinking, while descriptive studies evaluating creativity based on variables such as age, gender, the family's educational status etc. have produced conflicting results.

\section{Rationale for the Study}

Creative thinking skills are thought of as an important goal in developed countries at all education levels from preschool to the university level, and education programs are prepared accordingly. For an individual to think creatively, he or she should be able to come up with new ideas and solutions. Science and technology classes are fundamentally important for helping students develop the ability to solve problems in different situations (Akçam, 2007). Since creative people can take society further by developing original ideas and products, creative thinking has become part of science education in 21st century (Yager, 2000).

The relationship between creative thinking and science classes points to the importance of science teachers. Thinking creatively is important for teachers, whose job is to train individuals who can think creatively. Therefore, preservice science teachers and their critical thinking are focal point in this study. The aim of this study was to evaluate the levels of creative thinking of preservice science teachers who have received education in the department of science teaching and to analyze the data in terms of different variables such as gender, year of study, parents' educational background and the type of school they graduated from. The following research questions were examined:

1. Are there any significant differences between preservice science teachers' creative thinking scores with respect to gender?

2. Are there any significant differences between preservice science teachers' creative thinking scores with respect to year of study?

3. Are there any significant differences between preservice science teachers' creative thinking scores with respect to the type of school they graduated from?

4. Are there any significant differences between preservice science teachers' creative thinking scores with respect to their mother's educational background?

5. Are there any significant differences between preservice science teachers' creative thinking scores with respect to their father's educational background?

\section{Methodology of Research}

In this study, the survey model was used to determine the creative thinking levels of preservice science teachers in terms of different variables. An attempt was made to determine whether or not variables such as gender, year of study, the type of school they graduated from and their parents' educational background have any impact on creative thinking skills and if so, what degree of impact they have.

Survey models are research approaches that aim to describe a situation in the present or past. The case, person or object that is the subject of the research is described in its own situation (Karasar, 2009).

\section{Participants}

The working group comprised of 241 preservice science teachers, which represents $51 \%$ of 470 students being educated in the Mehmet Akif Ersoy University's Education Faculty in Turkey. These students were chosen randomly from first, second, third, and fourth-year students in the 2011-2012 Academic Year. 


\section{Data Collection Tools}

Two different scales were used as data collection tools in the study: first, an Individual Information Form, prepared by the researcher, and second, the Torrance Tests of Creative Thinking Figural Form A. Information about data collection tools is provided below.

Individual Information Form

This form was prepared to gather information about the sampling group and includes questions such as the preservice science teachers' age, gender, year of study, the type of school they graduated from, and their mother and father's educational background.

\section{Torrance Tests of Creative Thinking (TTCT)}

In order to measure the creative thinking skills of preservice science teachers, The Torrance Tests of Creative Thinking were used in this study. It was developed by Torrance in 1966 (Torrance, 1972). This test, which is made up of two verbal parts and two formal parts, includes the following sub-dimensions:

- Fluency: producing many ideas and associations

- Flexibility: producing different ideas from the same stimulus using different approaches,

- Originality: producing new, uncommon and rare ideas,

- Elaboration: processing and developing a given stimulus in an elaborated and careful way.

The Torrance Tests of Creative Thinking Figural Form A that was implemented in this study as data gathering tool, comprised of three activities. These activities are picture construction, picture completion and parallel lines. The test took 30 minutes to administer. According to Tavsancıl (2002), Pearson Correlation Coefficient can be used for interrater reliability. With this aim, two researchers evaluated thirty participants' papers. It was found that there was a strong and positive correlation between two researchers evaluations ( $r=0.98, n=30, p=0.000)$. In other words interrater reliability of the Torrance Tests of Creative Thinking Figural Form A for this study is acceptable according to Tavşancıl (2002). Permission was obtained from Institute for Wunderkind which holds the rights for broadcasting and printing Torrance tests in Turkey.

\section{Data Analysis}

In this study analysis of variance (ANOVA) were used for data analysis. ANOVA compare the variances of groups and involves one independent variable, which has a number of different levels (Gravetter \& Wallnau, 2004; Pallant, 2001). Scores (sum of fluency, flexibility, originality and elaboration scores) taken from Torrance Tests of Creative Thinking Figural Form A was taken as the dependent variable.

\section{Results of Research}

Pre-service science teachers'TTCT scores have been given in Table 1.

Table 1. TTCT scores of preservice science teachers.

\begin{tabular}{cccccc}
\hline & N & Minimum & Maximum & Mean & SD \\
\hline TCTT & 241 & 48.00 & 308.00 & 172.92 & 46.70 \\
Total & 241 & & & & \\
\hline
\end{tabular}

Based on Table 1, it is evident that the minimum score of pre-service science teachers' TTCT was 48.00, the maximum score was 308.00 and the average score was 172.92 .

Table 2 shows the results of ANOVA that was carried out to determine whether or not there was a significant difference between TTCT scores regarding pre-service science teachers' gender. 
Table 2. ANOVA results of pre-service science teachers'TTCT scores with respect to gender.

\begin{tabular}{cccccc}
\hline Source of Variance & Sum of Squares & df & Mean of Squares & F & p \\
\hline Between Groups & 3596.38 & 1 & 3596.38 & 1.65 & $0.20^{*}$ \\
Within Groups (error) & 519877.12 & 239 & 2175.22 & & \\
Total & 523473.50 & 240 & & & \\
\hline${ }^{*} p>0.05$ &
\end{tabular}

According to Table 2, the TTCT scores of preservice science teachers do not show a significant difference with respect to gender $\left(F_{1-239}=1.65 ; p>0.05 ; \eta^{2}=0.007\right)$. The test's effect $(0.007<0.06)$ and power $(0.249<0.80)$ were found to be small. As a result of the analysis, the average score of the females was found to be 175.82 and the average score of the males was found to be 167.78 .

Table 3 shows the results of the ANOVA test that was carried out to determine whether or not there was a significant difference between scores that preservice science teachers obtained from TTCT with regard to the teachers' year of study.

Table 3. ANOVA results of pre-service science teachers'TTCT scores with respect to year of study.

\begin{tabular}{cccccc}
\hline Source of Variance & Sum of Squares & df & Mean of Squares & F & p \\
\hline Between Groups & 13171.69 & 3 & 4390.56 & 2.04 & $0.109^{*}$ \\
Within Groups (error) & 510301.82 & 237 & 2153.17 & & \\
Total & 523473.50 & 240 & & & \\
\hline${ }^{*} p>0.05$ & &
\end{tabular}

According to Table 3, TTCT scores of preservice science teachers do not show a significant difference with respect to the year of study $\left(F_{3-237}=2.04 ; p>0.05 ; \eta^{2}=0.025\right)$. The test's effect $(0.025<0.06)$ and power $(0.519<0.80)$ were found to be small. The analysis shows that the average score of first year preservice science teachers was 175.12 , the average score of second year preservice science teachers was 163, the average score of third year preservice science teachers was 175.37, and the average score of fourth year preservice science teachers was 184.22.

Table 4 shows the results of ANOVA performed to determine whether or not there was a significant difference between TTCT and the type of high school the preservice science teachers graduated from.

Table 4. ANOVA results of pre-service science teachers' TTCT scores with respect to the type of school they graduated from.

\begin{tabular}{cccccc}
\hline Source of Variance & Sum of Squares & df & Mean of Squares & F & p \\
\hline Between Groups & 18683.19 & 5 & 3736.64 & 1.74 & $0.126^{*}$ \\
Within Groups (error) & 504790.31 & 235 & 2148.04 & & \\
Total & 523473.50 & 240 & & & \\
\hline${ }^{*} p>0.05$ & &
\end{tabular}

According to Table 4, pre-service science teachers'TTCT scores don't show a significant difference with respect to the type of school they graduated from $\left(F_{5-235}=1.74 ; p>0.05 ; \eta^{2}=0.036\right)$. The test's effect $(0.036<0.06)$ and power $(0.594<0.80)$ were found to be small. The analysis shows that the average score of preservice science teachers who graduated from general high schools was 167.79 , the average score of those who graduated from Anatolian high schools was 186.27, the average score of those who graduated from technical high schools was 186.57, the average score of those who graduated from vocational high schools was 180.25 , and the average scores of those who graduated from other schools was 179.33 .

Table 5 shows the results of the ANOVA test performed to determine whether or not there was a significant difference between scores that preservice science teachers obtained from TTCT and the mother's educational background. 
Table 5. ANOVA results of pre-service science teachers' $\mathrm{TTCT}$ scores with respect to the mother's educational background.

\begin{tabular}{cccccc}
\hline Source of Variance & Sum of Squares & df & Mean of Squares & F & p \\
\hline Between Groups & 6516.63 & 5 & 1303.33 & 0.59 & $0.706^{*}$ \\
Within Groups (error) & 516956.87 & 235 & 2199.82 & & \\
Total & 523473.50 & 240 & & & \\
\hline$" p>0.05$ & &
\end{tabular}

Table 5 indicates that pre-service science teachers' $T$ TCT scores do not show a significant difference with respect to the mother's educational background $\left(F_{5-235}=0.59 ; p>0.05 ; \eta^{2}=0.012\right)$. The test's effect $(0.012<0.06)$ and power $(0.215<0.80)$ were found to be small. The results of the analysis showed that the average score of preservice science teachers who had illiterate mothers was 171.45 , the average score of those who had literate mothers was 179.67 , the average score of those with mothers who were primary school graduates was 169.78 , the average score of those with mothers who were secondary school graduates was 173.37 , the average score of those with mothers who were high school graduates was 185.81 , and the average score of those with mothers who were university or higher education graduates was 175.27 .

Table 6 shows the results of ANOVA performed to determine whether or not there was a significant difference between scores that preservice science teachers obtained from TTCT and the father's educational background.

Table 6. ANOVA results of pre-service science teachers' TTCT scores with respect to the father's educational background.

\begin{tabular}{cccccc}
\hline Source of Variance & Sum of Squares & df & Mean of Squares & F & p \\
\hline Between Groups & 18117.37 & 6 & 3019.56 & 1.40 & $0.216^{*}$ \\
Within Groups (error) & 505356.11 & 234 & 2159.64 & & \\
Total & 523473.50 & 240 & & & \\
\hline${ }^{*} p>0.05$ & & & &
\end{tabular}

Table 6 indicates that preservice science teachers' TTCT scores do not show a significant difference with respect to the father's educational background $\left(F_{6-234}=1.40 ; p>0.05 ; \eta^{2}=0.035\right)$. The test's effect $(0.035<0.06)$ and power $(0.541<0.80)$ were found to be small. The analysis shows that average score of preservice science teachers who have illiterate fathers is 160.60 , the average score of those who have literate fathers was 168.29 , the average score of those whose fathers are primary school graduates is 167.49 , the average score of those whose fathers are secondary school graduates is 181.63 , the average score of those whose fathers are high school graduates is 181.35 , the average score of those whose fathers are university or higher education graduates is 166.31 , and the average score of those whose fathers have postgraduate education is 228.00 .

\section{Discussion}

The findings of this study, which was carried out to determine preservice science teachers' creativity levels in terms of different variables such as gender, year of study, types of school they graduated from and educational background of mothers fathers, is discussed under the following headings.

\section{Findings Regarding the First Sub-problem}

The TTCT scores of preservice science teachers do not show a significant difference with respect to gender. In other words, the factor of gender does not have a significant effect on creative thinking. The findings of studies done by Güngör (2007), Ercan (2003), Potur and Barkul (2009) and Konak (2008) support the results obtained in this study. For example Konak (2008) states that girls and boys have similar artistic creativity, which is congru- 
ent with our results. Studies on the relationship between creative thinking scores and gender have produced different results than the sample and research model. Many studies are being carried out on this subject. Some of these studies indicate that gender differences do not have an effect on creative thinking, while others show that men are more creative. The claim is made that the difference is because men are more interested in science, engineering, technology than women (Boling, Boling and Eisenman, 1993; Baer, 1997). In experimental studies carried out by Yaman and Yalçın (2005) with 220 preservice science teachers studying in the department of primary school teaching, it is evident that in experimental and control groups, female students' creative thinking scores both in pre-test and posttest are higher than male students. The authors propose that the reason for this is that female students are more eager to do activities related to drawing than are male students. In a study by Öztunç (1999), a significant difference is found between gender and creative thinking levels that favors female students. The author states that the reason for this is that families care more about female children than male children. However, Öztunç's study (1999) is different from this study in that Öztunç (1999) carried out his study with fifth-grade students.

\section{Findings Regarding Second Sub-problem}

The TTCT scores of preservice science teachers do not show a significant difference with respect to the student's year of study. Even though some groups'TTCT scores were higher than others, these differences were not found to be statistically significant. As a result, the factor of pre-service science teachers' year of study does not have a significant effect on creative thinking levels. Studies about creativity and a student's year of study draw attention to the relationship between creativity and age. Kaynak (2006) claims that it is impossible to use different results from different studies to draw a correlation between creative thinking and age. These different results about age and creativity must be taken into consideration with respect to creative person, creative environment, creative process and creative product rather than age variable. Because every person has creativity potentially, and creative person, creative environment, creative process and creative product affect the improvement and rustiness of this creativity.

\section{Findings Regarding Third Sub-problem}

The TTCT scores of preservice science teachers do not show a significant difference with respect to the type of school they graduated from. In other words, the type of schooling of preservice science teachers does not have a significant effect on creative thinking levels. In a study on the effect of the problem based teaching approach on creative thinking carried out with class pre-service teachers, Yaman and Yalçın (2005) did not find a significant difference between creative thinking and preservice teachers with high school education in the experimental group, but they did find a significant difference in the control group's post-test scores. This result was interpreted as indicating that high school graduates who have better tests scores when applying to undergraduate programs are better at creative thinking. In addition, Çetingöz (2002) performed a study with 116 students from the preschool teaching department, which indicates that there are no significant differences between TTCT verbal scores and the type of school a student graduated from.

\section{Findings Regarding Fourth Sub-problem}

The TTCT scores of preservice science teachers do not show a significant difference with respect to the educational background of the teacher's mother. As a result, the factor of the pre-service science teachers' mother educational background does not have a significant effect on his or her creative thinking levels. Studies by Konak (2008) and Çetingöz (2002) indicate that there is no significant difference between formal creative scores and the mother's educational background. In a study by Şen (1999) that was carried out with 170 nurse candidates, no significant relationship was found between the mother's educational background and the creative thinking dimensions of fluency, flexibility and originality. 


\section{Findings Regarding Fifth Sub-problem}

It was found that the TTCT scores of preservice science teachers also do not show a significant difference with respect to the educational background of the teacher's father. In other words, the factor of the father's educational background does not have a significant effect on a teacher's creative thinking levels. This result concurs with the findings of studies done by Konak (2008) and Çetingöz (2002). Şen (1999) reported that the relationship between the father's educational background and the creative thinking dimensions of fluency and flexibility.

\section{Conclusions}

Creative thinking has become an essential part of our daily life. There is a need for creative individuals who can handle the problems we face and help society advance with new and unique inventions. Consequently, educators have a big role to play in encouraging creative thinking, which has become one of the fundamental principles of contemporary educational philosophy. Throughout the educational process, teachers also need to be creative, open to creative ideas and they must support the creative process. Thus the creativity of preservice teachers who will be teachers and train our children in the future, becomes important. This study aimed to determine the creative thinking of preservice science teachers who have received education in the department of science teaching in terms of different variables such as gender, year of study, parents' educational background and the type of school they graduated from. Survey method that aims to describe a situation in the present was used. According to data analysis the TTCT scores of preservice science teachers do not show a significant difference with respect to gender, year of study, parents' educational background and the type of school they graduated from. In other words, the factor of gender, year of study, parents' educational background and the type of school they graduated from do not have a significant effect on creative thinking. However, the limitation that this study is limited with the preservice science teachers in Mehmet Akif Ersoy University Education Faculty in Turkey should be taken into consideration when interpreting the results. As regards to results from this study, some suggestions can be made to researchers deal with creative thinking and education. First, in most of studies that are especially incoherent with this study's result, sub-dimensions of creative thinking were investigated. In this study total score was evaluated as creative thinking score. Namely, sub-dimensions that are flexibility, fluency, originality and elaboration were not analysed. Total scores cannot provide the information about sub-dimensions of creative thinking. So, a study that will be made by using sub-dimensions can provide may be interesting results. Second, longitudinal study can be made during the four years of same preservice science teachers. Thus, especially age/study year factor can be observed on the same person.

\section{Acknowledgements}

This study is a part of a master's thesis written by Esra Öztekin, who was mentored by Assist. Prof. Dr. Selda Bakır at Mehmet Akif Ersoy University in 2013.

\section{References}

Açıkgöz, K.Ü. (2003). Etkili öğrenme ve öğretme (Active learning and teaching). İzmir: Eğitim Dünyası Yayınları.

Adıgüzel, H,Ö.(2002). (Editör). Yaratıcı drama 1985-1995 yazıları (1985-1995 writings of creative drama). Ankara: Natürel Kitap Yayıncilık.

Akçam, M. (2007). Illköğretim fen bilgisi derslerinde yaratıcı etkinliklerin öğrencilerin tutum ve başarılarına etkisi (Effects of creative activities on students' attitudes and achievements in primary school science courses). Yayımlanmamış Yüksek Lisans Tezi (Unpublished Master Thesis), Balıkesir Üniversitesi ( Balıkesir University), Balıkesir.

Aksoy, G. (2005). Fen eğitiminde yaratıc düşünme temelli bilimsel yöntem sürecinin öğrenme ürünlerine etkisi ( The effect of the scientific method process, which is based on creative thinking, on the learning outcomes in science instruction). Yayımlanmamış Yüksek Lisans Tezi (Unpublished Master Thesis), Zonguldak Karaelmas Üniversitesi (Zonguldak Karaelmas University), Zonguldak.

Argun, Y. (2004). Okul öncesi dönemde yaratıcılık ve eğitimi (Creativity and its importance in preschool). Ankara: Anı Yayıncılık. Artut, K. (2004). Sanat eğitimi kuramları ve yöntemleri (Art education theories and methods). Ankara: Anı Yayıncılık. 
Atay, Z. (2009). Okul Öncesi Eğitim Kurumlarına Devam Eden 5-6 Yaş Öğrencilerinin Yaratııllık Düzeylerinin Yaş, Cinsiyet ve Ebeveyn Eğitim Durumlarına Göre Incelenmesi: Ereğli Örneği(Examination of 5-6 years old students attending pre- school education institutions according to the creativity levels, age, gender and parental educational background: Ereğli sample). Yüksek Lisans Tezi (Master thesis). Selçuk Üniversitesi (Selcuk University), Konya.

Baer, J. (1997). Gender differences in the effects of anticipated evaluation on creativity. Creativity Research Journal, 10, (1), 2531.

Barok, M. (2009). Idea focusing versus idea generating: A course for teachers on inventive problem solving. Innovations in Education and Teaching International, 46 (4), 345-356.

Boling, S.E., Boling, J.L., \& Eisenman, R. (1993). Creativity and birth order/sex differences in children. Education, 114. Retrieved December 1, 2011, from http://www.questia.com/googleScholar.qst?docld=5000254689

Candar, H. (2009). Fen eğitiminde yaratıcı düşünme öğretim tekniklerini öğrencilerin akademik başarı, tutum ve motivasyonlarına etkisi (The effects of creative teaching techniques on students' academic achievement, attitude and motivation in science education). Yüksek Lisans Tezi (Master thesis). Marmara Üniversitesi (Marmara University), İstanbul.

Ceran, A. S. ( 2010). Yaratıcı düşünme teknikleri ile geliştirilen fen etkinliklerinin öğrenci başarısı ve tutumuna etkisi (Effect of science activities created with techniques of creative thinking to student's achievement and attitude). Yüksek Lisans Tezi (Master Thesis), Selçuk Üniversitesi (Selcuk University), Konya.

Çellek, T. (2004). Yaratıcılık ve eğitim sistemimizdeki boyutu (Creativity and its dimention in our educational system). Retrieved January 26, 2012, from http://www fotografya.gen.tr/issue16/goster.php?sayi=16\&dosya=temeltasarim index $16 \mathrm{htm}$

Çetingöz, D. (2002). Okulöncesi eğitimiöğretmenliğiöğrencilerinin yaratıcı düşünme becerilerinin gelişiminin incelenmesi (Theexamination of the development of the creative thinking skills of the students in the preschool teacher training program). Yayınlanmamış Yüksek Lisans Tezi (Unpublished Master Thesis). Dokuz Eylül Üniversitesi (Dokuz Eylul University), İzmir.

Davidovitch, N., \& Milgram, R. M. (2006). Creative thinking as a predictor of teacher effectiveness in higher education. Creativity Research Journal, 18(3), 385-390.

Demirel, Ö. (1993). Yaratıcılık ve eğitim (Creativity and education). Ankara: Türk Eğitim Derneği Yayınları.

Edgar, D. W., Faulkner, P., Franklin, E., Knobloch, N. A., \& Morgan, A. C. (2008). Creative thinking: opening up a world of thougth. Retrieved November 20, 2011, from http://www.acteonline.org

Ercan, D. (2003). Yaratıılığın matematik başarısına etkisi (The Effect of creativity on the mathematical success). Yayımlanmamış Yüksek Lisans Tezi (Unpublished Master thesis). Dokuz Eylül Üniversitesi (Dokuz Eylul University), Izmir.

Ercan, S. (2010). Fen eğitiminde yaratıı düşünme tekniklerinden sinektik kullanımına yönelik bir eylem araştırması (The action research releated synectic technique in science education). Yüksek Lisans Tezi (Master thesis). Sakarya Üniversitesi (Sakarya University), Sakarya.

Ersükmen, E. (2010). illköğretim fen ve teknoloji ders öğretmenlerinin yaratıcılık kavramına ilişkin görüşleri (The ideas related the creativity of primary school science and techonology teachers). Yüksek Lisans Tezi (Master thesis). Dokuz Eylül Üniversitesi (Dokuz Eylul University), Izmir.

Gravetter, F., Wallnau, L. B. (2004). Statistic for the behavioral sciences. USA: Thomson Wadsworth.

Guilford, J.P. (1950). Creativity. American Psychologist, 5, 444-454.

Güngör, İ. (2007). Anadolu lisesi öğrencilerinin yaratıcı düşünme düzeylerinin kişisel uyum, sosyal uyum, genel yetenek ve akademik başarı ile ilişkisi (The relationships creative thinking levels and personal adaptation, social adaptation, general ability and academic success among Anatolian high school students). Yüksek Lisans Tezi (Master thesis). Ankara Üniversitesi (Ankara University), Ankara.

Haláková, Z. (2007). Is creativity characteristic for incoming teachers of science?. Problems Of Educaion in The 21st Century, 1, 39-43.

Hu, W., \& Adey, P. (2002). A scientific creativity test for secondary school students. International Journal of Science Education, 24, (4), 389-403.

Kaptan, F., \& Kuşakcı, F. (2002). Fen öğretiminde beyin fırtınası tekniğinin öğrenci yaratıcılığına etkisi (The effects of brain storming technique on student's creativity in science education). Retrieved December 1, 2010 from http://www.fedu.metu.edu.tr/ ufbmek 5/b_kitabi/PDF/Fen/Poster/t50d.pdf

Karasar, N. (2009). Bilimsel araştırma yöntemleri (Scientific research methods)(pp.77). Ankara: Nobel Yayın Dağıtım.

Karkockiene, D. (2005). Creativity: Can it be trained? A scientific educology of creativity. International Journal of Educology, Lithuanian Special Issue. Retrieved March 8, 2014 from files.eric.ed.gov/fulltext/ED494897.pdf.

Kaynak, M. (2006). Erciyes Üniversitesi Güzel Sanatlar Fakültesi öğrencileri ile Mimarlık Fakültesi öğrencilerinin yaratıcı yetenek düzeyleri açısından karşılaştırılması (The comparison of creative ability level between Erciyes University Fine Arts Faculty and Architecture Faculty students). Yayınlanmamış Yüksek Lisans Tezi (Unpublished Master Thesis). Erciyes Üniversitesi(Erciyes University), Kayseri.

Kırışoğlu, O. T. (2002). Sanatta eğitim görmek-öğrenmek-yaratmak (Seeing-learning-creating in art). Ankara: Pegem A Yayıncılık, 190-195.

Kim, H. K., Lee A. E., \& Seo H. (2005). Korean science teachers' understanding of creativity. The Journal of Secondary Gifted Education, 16, 98-105.

Konak, A. (2008). Illköğretim 6. sınıf öğrencilerinin sanatsal yaratıcılık düzeyleri (Sixth grade students' artistic creativity levels). Yayınlanmamış Yüksek Lisans Tezi (Unpublished Master Thesis), Süleyman Demirel Üniversitesi (Suleyman Demirel University), Isparta. 
Korkmaz, H. (2002). Fen eğitiminde proje tabanlı öğrenmenin yaratıcı düşünme, problem çözme ve akademik risk alma düzeylerine etkisi (The effects of project based learning on creative thinking ability, problem solving ability and level of academic risk taking in science education). Yayınlanmamış Doktora Tezi (Unpublished Doctoral Thesis). Hacettepe Üniversitesi (Hacettepe University), Ankara.

Lee, Y. J. (2004). Effects of divergent thinking training: Instructions on Torrance Tests of Creative Thinking and creative performance. Doctor of Philosophy Degree. The University of Tennesse, Knoxville.

Neira, J. A. P., \& Soto, I. R. S. (2013). Creativity and physics learning as a product of the intervention with conceptual maps and Gowin's V Diagrams. Creative Education, 4(12A), 13-20.

Newton, D. P., \& Newton, L. D. (2009). Some student teachers' conceptions of creativity in school science. Research in Science \& Technological Education, 27, (1), 45-60.

Oğuz, M. (2002). İlköğretim fen bilgisi dersinde yaratıcı problem çözme yönteminin başarıya ve tutuma etkisi (The Effects creative problem solving method on success level and attitude educational science knowledge lesson). Yayımlanmamış Yüksek Lisans Tezi (Unpublished Master Thesis). Hacettepe Üniversitesi (Hacettepe University), Ankara.

Ömeroglu, E., \& Turla, A., (2001). Okulöncesi dönemde yaratıclık eğitimi ve desteklenmesi (Creativity education and supporting of creativity in preschool time). Milli Eğitim Dergisi(Journal of National Education), 151.

Öncü, T. (1989). Torrance Yaratıcı Düsünme Testleri ve Wartegg-Briedma Testi aracılığılla 7-11 yaş çocuklarının yaratıcılığı ve kişilik yapıları arasındaki ilişkinin incelenmesi. Yayımlanmamış Doktora Tezi (Unpublished Doctoral Thesis). Ankara Üniversitesi (Ankara University), Ankara.

Özben, S. \& Argun, Y. (2000). Üniversite öğrencilerinin yaratıclık düzeylerinin karşılaştırılması. IX. Ulusal Eğitim Bilimleri Kongresi Bildiri Özetleri. Erzurum: Atatürk Üniversitesi Kazım Karabekir Eğitim Fakültesi Yayınları.

Özden, Y. (1999). Öğrenme ve öğretme (Learning and teaching). Ankara: Pegem A Yayıncılık.

Öztunç, M. (1999). Yaratıcı düşünce üzerinde ailenin etkisi (The effect of family on creative thinking). Yüksek Lisans Tezi (Master Thesis). Sakarya Üniversitesi (Sakarya University), Sakarya.

Öztürk, Ş. (2004). Eğitimde yaratıcı düşünme (Creative thinking in education). Ondokuz Mayıs Üniversitesi Eğitim Fakültesi Dergisi (Ondokuz Mayıs University Journal of Education Faculty), 18, 77-84.

Öztürk, K. S. (2007). Yaratıı düşünmeye dayalı öğrenme yaklaşımının öğrencilerin yaratıcı düşünme ve problem çözme becerilerine etkisi (The effect of the learning approach based on creative thinking upon the creative thinking and problem solving skills of students). Yüksek Lisans Tezi (Master Thesis).Eskişehir Osmangazi Üniversitesi (Eskisehir Osmangazi University), Eskisehir.

Pallant, J. (2001). SPSS survival manual: A step by step guide to data analysis using SPSS for Windows (Version 10). Philadelphia, USA: Open University Press.

Plucker, J. A., \& Nowak, J. A. (2001). Creativity in science for K-8 practitioners: Chapter 10. In Edited by M. D. Lynch, \& C.R. Harris (Eds.), Fostering creativity in children, K-8. USA: Allyn\& Bacon.

Potur, A., \& Barkul, Ö. (2009). Gender and creative thinking in education: A theoretical and experimental overview. ITU Journal of Faculty of Architecture, 6, (2), 44-57.

Rawlinson, J. G. (1995). Yaratıcı düşünme ve beyin fırtınası (Creative thinking and brain storming). (Çev: Değirmen, O.). Rota Yayıncılık: İstanbul.

Razon, N. (1990). Yaratıcılığı geliştirici oyunla eğitim (Education with game developing creativity). Çağdaş Eğitim, Çağdaş Yaşamı Destekleme Derneği. Retrieved November 24, 2010 from http://www.ekipnormarazon.com

Singer, D. G., \& Singer, J. L. (1998). Çocuklarda Yaratıcılığın Gelişimi (Development of creativity on children). (Çev.: Cihanşümul, N.). İstanbul: Gendaş Yayıncılık.

Stenberg, R.,J., \& Lubart, T. I. (1993). Investing in creativity. Psychological Inquiry, 4, (3), 229-232.

Stephens, L. M. (2010). Problem-based learning in an elementary social studies class. Master of Arts. Caldwell College, New Jersey. Retrieved March 10, 2014 fromhttp://proquest.umi.com/pqdweb

Sungur, N. (2003). Işıltılı bilmeceler (Sparkling puzzles). (1. Baskı). İzmit: Sesim Ofset Matbaacılık.

Süzen, D. (1987). illkokul 5. sını öğrencilerinde yaratıcı düşünme yeteneği ile benlik kavramı arasındaki ilişki. Yüksek Lisans Tezi (Unpublished Master Thesis). Hacettepe Üniversitesi (Hacettepe University), Ankara.

Süzen, S. (2007). Aktif öğrenme teknikleriyle desteklenmiş fen ve teknoloji eğitiminin öğrenme ürünlerine etkisi (The effect of the scince and technology education supported by active learning techniques on learning outcomes). Yayımlanmamış Doktora Tezi (Unpublisehed Doctoral Thesis). Gazi Üniversitesi (Gazi University), Ankara.

Şen, H. (1999). Yaratıcı düşünmenin hemşirelik yüksekokul öğrencilerinde incelenmesi (Examining of the creative thinking over the students of nursing school). Yüksek Lisans Tezi (Master thesis). Dokuz Eylül Üniversitesi (Dokuz Eylul University), Izmir.

Tavşancıl, E. (2002). Tutumların ölçülmesi ve SPSS ile veri analizi (Measuring the attitudes and data analysis with SPSS). Ankara: Nobel Yayıncilık.

Tegano, D. W., \& Moran, J. D. (1989). Sex differences in the original thinking of preschool and elementary school children. Creativity Research Journal, 2 (1-2), 102.

Torrance, E. P. (1972). Torrance Tests of Creative Thinking: Directions manual and scoring guide- Figural Test Booklet A. Lexington: Personnel Press.

Torrance, E. P. (1974). Norms- technical manual: Torrance Tests of Creative Thinking. Bensenville: Scholastic Testing Service.

Torrance, E. P., \& Goff, K. (1979). A quiet revolution. The Journal of Creative Behavior, 23, (2), 136-145.

Üstündağ, T. (2009). Yaratıcılığa yolculuk (Journey into creativity). Ankara: Pegem A Yayıncılık. 
Yager, R. E. (2000). A Vision for what science education should be like for the first twenty-five years of a new millennium, School Science and Mathematics, 100, 327-341.

Yaman, S., \& Yalçın N. (2005). Fen bilgisi öğretiminde probleme dayalı öğrenme yaklaşımının yaratıcı düşünme becerisine etkisi (Effectiveness on creative thinking skills of problem based learning approach in science teaching). Ilköğretim Online, 41 (1), 42-52.

Yavuzer, H. (1989). Yaratııılık (Creativity). (3. Basım). İstanbul: Boğaziçi Üniversitesi Yayınları.

Yıldırım, R. (1998). Yaratıcılık ve yenilik (Creativity and innovation). İstanbul: Sistem Yayıncılık.

Yontar, A. (1993). İnsanda yaratıcılığın gelişimi (The development of creativity on human). Yaratıcılık ve Eğitim, 15-29.

Received: October 23, 2013

Accepted: March 15, 2014

Selda Bakır

(Corresponding Author)
PhD., Assistant Professor, Department of Elementary Education, Faculty of Education, Istiklal Campus, Mehmet Akif Ersoy University, 15030, Burdur, Turkey.

Phone: +90 24821341 14. Fax: +90 2482346009 .

E-mail: sbakir@mehmetakif.edu.tr; seldacu@hotmail.com Website: http://abs.mehmetakif.edu.tr/sbakir

Esra Öztekin Master of Science Education E-mail: esraztkn@gmail.com 